\title{
THE MODEL ASSESSING THE IMPACT OF PRICE AND PROVIDED SERVICES ON THE QUALITY OF THE TRIP BY TRAIN: MCDM APPROACH
}

\section{Henrikas Sivilevičius, Lijana Maskeliūnaité}

\section{Introduction}

In recent years, the problems of diverse transport mode development policy, travel price, duration and quality have been solved by a wide range of international scientists and researchers (Kandt, Rode, Hoffman, Graff, \& Smith, 2015; Seelhorst \& Liu, 2015; Woo, Cheng, Li, Chiu, Ho, \& Horowitz, 2015; Kirschstein \& Meisel, 2015; Guo, Yu, Chen, \& Zhang, 2011). The choice of a particular mode of transport as an alternative to another one is subjective and usually based on an individual passenger's approach to the evaluation of advantages and disadvantages of some particular means of transport (Sivilevičius \& Maskeliūnaitè, 2018).

A transport system is a system created for transporting large numbers of passengers at the low price of investment. Passengers can usually choose a means of transport based on the criteria, which seem to be important for them. Passengers differently assess the advantages and disadvantages of particular transport facilities. This primarily applies to traffic safety, control, price and conditions of transportation (comfort), as well as the time of transporting passengers to their destination (Batley, Dargay, \& Wardman, 2011; Chen, Leng, Mao, \& Liu, 2014; Börjesson, 2014; Guo \& Wilson, 2011; Dlamini, 2011).

A structural equation model is formulated to explore the impact of the relationship between global customer satisfaction and service quality attributes, such as safety, cleanliness, main and additional services, information about the service, and personnel, and to verify which of these attributes are key factors of service quality. Services offered by rail operations in Northern Haly are analyzed (32 regional lines, 9 suburban lines, 2 express lines) (Eboli \& Mazzulla, 2015). A multilevel fuzzy synthetic evaluation model to evaluate the service quality is proposed based on the fuzzy theory
(Eboli, Fu, \& Mazzulla, 2016). An evaluation indicator system with three grades evaluation indicators is established, and their weights are determined on the basis of opinions expressed by interviewed passengers. Railway service quality is evaluated by the value of a comprehensive satisfaction degree. Miranda, Tavares and Queiró (2018) investigate whether different combinations of service quality dimensions affect customer satisfaction. The study uses an extension of SERVQUAL with dimensions specific to the railway industry: comfort, connection, and convenience. Here we use a fsQCA to examine the responses from an online survey of 352 railway customers. The result show that three different combinations of the service quality dimensions lead to overall customer satisfaction.

In the paper of De Oña, Eboli and Mazzulla (2014), the analysis of the rail Service Quality (SQ) performed on the basis of users' perceptions, expressed in terms of satisfaction and importance assigned to various service characteristics, is presented. SQ and customer satisfaction as perceived by 1,037 passengers on intercity train services (Hadiuzzman, Farazi, Hossain, \& Malik, 2017). This study analyzes the effects of observed and latent variables related to intercity train on its overall $S Q$ in the context of developing countries. To this end, structural equation model (SEM), an advanced modeling technique which permits incorporation of exogenous, endogenous and latent variables is used. Two different models are developed for identifying the structure that can accurately represent the perceived $S Q$ of intercity train users.

Supplying public transport systems with high levels of service quality is fundamental for retaining users and attracting new ones. Policies that improve transit service quality will ultimately lead to more sustainable travel 
patterns. Measuring overall service quality implies measuring the quality of several specific attributes and is prevalently evaluated through the perceptions of users, using satisfaction rates (Allen, Eboli, Mazzulla, \& Ortúzar, 2018). Passenger transport quality has an impact on tourism development in the country. Albaladejo and González-Martinez (2018) use a nonlinear dynamic specification to model international tourism demand on the Spanish Mediterranean coasts, and investigates how previous tourists can affect tourism demand decisions. The aim of the work (De Oña, J., De Oña, R., \& Mazzulla, 2015 ) is to analyze the different perceptions among groups of users regarding transit service quality. Here propos a methodology based on a classification and regression tree (CART) approach, allowing the characteristics that most influence overall service quality to be identified. Passengers expressed their opinions about service characteristics such as safety, cleanliness, comfort, information, and personnel.

Knowing passengers' behavioral intentions to use transit service can be a useful support for transit managers and marketers who can define the most convenient strategies to satisfy existing passengers and attract new ones (De Oña, J., De Oña, R., Eboli, Forciniti, \& Mazzulla, 2016). De Oña, J., De Oña, R., Eboli, Forciniti and Mazzulla (2016) propose a structural equation model for investigating on the relationship among some aspects influencing passengers' behavioral intentions towards the use of transit services. Paha, Rompf and Warneeke (2013) studied the determinants of customers' behavior in passenger rail competition on two cross-border routes, Cologne-Brussels and Cologne-Amsterdam. This study fills a gap in the literature on the competition in the sector of commercial passenger rail transportation by relying on the newly collected state performance data obtained from about 700 on-train interviews. Under the conditions of fierce competition, transport facilities should be constantly improved and upgraded (Avdovskiy, 2013). The main purpose of railway transport is to carry a maximum number of customers and loads on the planned or existing lines at the minimum investment price, personnel, equipment, energy consumption, as well as operating and maintenance price (Hansen, 2010).

In studying the economic efficiency and practical aspects of railway transport operation, a great number of the research methods and decision making approaches, including programming and balancing, decisionmaking optimization, mathematical-economic, statistical and operational research, as well as expert evaluation, ranking, etc., are widely used (Belov, Tereshina, Galaburda et al., 2001). New decisions are also made to determine the economic efficiency of long-distance trains. New methods and the results obtained in determining the economic efficiency of rail transport help to identify the most unprofitable trains. Marketing specialists analyze the causes of their unprofitability and offer the adequate measures for reducing the losses. Thus, it is believed that the scheme of rolling stock formation may be changed and one or more passenger cars may be uncoupled (Miroshnichenko \& Oginskaja, 2013).

Christogiannis and Pyrgidis (2014) used a mathematical model to describe the impact of traffic operation on the profitability of a new railway line. The model allowed them to investigate various scenarios (e.g. mixed traffic operation and dedicated passenger operation, dedicated freight operation, etc.), primarily, for calculating the economic profitability of each scenario (net present value, NPV), as well as the internal rate of return of investment). It also helped the authors to select the scenario of railway operation with the highest economic profitability based on the demand for passenger and freight transportation via the new line. The evaluation of the railway line capacity is an important task associated with various problems in rail transportation planning. The railway capacity depends on its infrastructure, traffic, and operating parameters. A key factor determining the railway line capacity is associated with the train types (Yaghini, Nikoo, \& Ahadi, 2014).

The control of train movement at large passenger railway stations is associated with a number of specific problems (e.g. delays of the incoming trains). The solution of these problems has a positive effect on the quality of services provided to passengers at stations, as well as the quality of services provided to passengers in the surrounding railway network (Jánošikova, Kavicka, \& Bazant, 2014).

Another significant criterion of the quality of the trip by train is safety, largely depending on track parameters. Jafarian and Rezvani (2012) presented a comprehensive study based on the 
fuzzy fault tree analysis (FTA) for evaluating the causes of the railway safety risk. First, the authors presented the introduction to the fuzzy set theory. Then, the proposed approach was implemented, using a real case study for risk assessment of the passenger train derailment. The study by Noorzaei, Pour, Jaafar, Fong and Thanoon (2012) dealt with the twodimensional, numerical simulation of a railway track supporting system subjected to the action of the dynamic excitation force. Under the plane-strain condition, the coupled finite-infinite elements for describing the distribution of the near and far field stresses and a thin-layer interface element were employed to model the interfacial behavior between the sleepers and the ballast.

Vehicle failures reduce traffic safety considerably. The performed data analysis was aimed at determining the number of vehicle breakdowns and their dependence on the vehicle's age, as well as the number of passengers and operations (Gelumbickas \& Vaičiūnas, 2011). The mathematical model described below analyses the correlation between the passenger fleet upgrade rate and the number of faults. The article by Vaičiūnas and Bureika (2014) offered a concept for creating the model of the passenger vehicle's failure rate depending on the mileage. According to this model, the renewal algorithm of the vehicle fleet can be created and used to considerably limit the fluctuation of the fleet's average failure rate and to achieve the most accurate correlation between the number of failures and the fleet's average mileage.

The major railway accidents in Great Britain, which occurred in the past 10 years, have shown that a significant number of fatalities and serious injuries were the result of the situations, when passengers were thrown out through the vehicle's windows. Nowell and Sutton (2011) described the work carried out to determine the circumstances related to passenger ejection and the performance of the existing glazing systems.

In recent years, MCDM (multiple-criteria decision making) methods have been widely used in solving transport problems. Hu and Liu (2014) adapted a mathematical programming method to develop a headway-oriented model for the Kaohsiung mass rapid transit (MRT) system aiming to minimize the system's price while maintaining an acceptable level of train services. The developed model systematically adjusts train headways based on time-series passengers' spatiotemporal distribution data.

Zhao and Deng (2013) developed a fuzzy multiobjective decision support model for urban rail transit projects in China under the conditions, when China was experiencing an unprecedented construction boom in urban rail transit. In this study, an appropriate model based on multilevel comprehensive fuzzy evaluation was considered. The results showed that this model is reliable and applicable to decision making in urban rail transit projects. Bajčetić, Tica, Živanović, Milovanović and Dorojević (2018) presents a case study using Quality Function Deployment (QFD) method to identify urban public transport users' needs and requests and to improve service quality in urban public passenger transport in Belgrade. In order to determine users' satisfaction, a direct interview - survey a sample of 15,000 of urban public passenger transport system users, according to the defined questionnaire has been performed.

Financial constraints necessitate the tradeoff among the proposed railroad projects, so that the project priorities for implementation and budget allocation need to be determined by the ranking mechanisms in the government. At present, the central government of Taiwan prioritizes funding allocations, primarily using the analytic hierarchy process (AHP), a methodology allowing for synthesizing subjective judgments systematically and logically into the objective consensus (Cheng, Su, Tsai, \& Lin, 2012).

Zalar, Užpalytè-Vitkūnienè, Rebolj and Lep (2018) presents a methodological framework for evaluating transport ticketing technologies with the use of a transport ticketing convenience model developed by the authors as well as some survey results through the application of the developed framework on traditional smart ticketing and contactless payment card ticketing technologies.

The evaluation of technological, economic, safety and quality factors of passenger transportation on an international route by expert methods was also performed (Maskeliūnaitè \& Sivilevičius, 2012; 2014). The lack of the data for evaluating passenger transportation quality on the route encouraged the authors (Sivilevičius, Maskeliūnaitè, Petkevičienè, \& Petkevičius, 2012) to develop a quantitative method and 
the $\mathrm{K}$ index, allowing them to objectively assess passenger transportation quality on an international route, expressing it by a single value. Bureika, Bekintis, Liudvinavičius and Vaičiūnas (2013) demonstrated the application of the AHP approach to performance evaluation through the case study of Lithuanian railway traffic risk. The results of the performed study showed that the application of the AHP method can help railway traffic control managers effectively evaluate the railway infrastructure objects from the perspective of traffic safety risk and make long-term strategic plans for preventing the accidents on the railway lines even under difficult economic and transportation conditions.

Decision making in engineering economics is based on using the MCDM methods, such as AHP, applied to evaluate the complexity of projects (Vidal, Marle, \& Bacquet, 2011), e-services and positioning of passenger ports in the context of cruise tourism promotion (Vitić-Ćetković \& Bauk, 2014), as well as the functionality comparison of health care systems (Šoltés \& Gavurova, 2014). It also includes FAHP (Fuzzy Analytic Hierarchy Process) and TOPSIS (Technique for Order Preference by Similarity to Ideal Solution) used to assess the photovoltaics industry (Lee, Kang, \& Lin, 2014). The use of TOPSIS grey methods in developing advertising strategies (Hashemkhani Zolfani, Rezaeiniya, Pourhossein, \& Zavadskas, 2012) and staff members' selection (Hashemkhani Zolfani \& Antucheviciene, 2012), the SWARA (Step-Wise Weight Assessment Ratio Analysis) method for determining the priority factors influencing the sustainable development of the power system (Hashemkhani Zolfani \& Saparauskas, 2013) as well as COPRAS-G (Complex Proportional Assessment with Grey relations) used for selecting machine tools (Aghdaie, Hashemkhani Zolfani, \& Zavadskas, 2013) were also described.

The present paper aims to suggest an original multicriteria mathematical model for evaluating the weights of six criteria, describing the price of the trip and the provided services (PTPS) by international train, as well as their influence on the comprehensive quality index (CQI), and to validate the results through the case study of the numerical CQI calculations made for the international train 'VilniusMoscow'.

\section{The Mathematical Model}

\subsection{A Basic Model}

The quality of travel by train (QTT) can be expressed as a sum of the calculated quantitative criteria $K_{A}, K_{B}, K_{C}$ and $K_{D}$. These criteria of groups A, B, C, D have a different influence on the determination of the QTT significance based on the calculation of the normalized subjective weights $\bar{Q}$ by multicriteria decision making methods: the stronger the influence, the larger the weight assigned to a particular criterion by experts or respondents. Subjective weights reflect the opinions of qualified experts with extensive theoretical and practical experience in the field. The weights mentioned above are most commonly used in practice (Zavadskas \& Podvezko, 2016). Multiplying the normalized weights $\bar{Q}$ of these quantitative criteria by their variable parts, $x$, yields the QTT expressed by a single value (index) $K$, which can range from 0 to 1 . The value of $x$ also varies from 0 to 1 . It depends on the real value of the considered criterion compared to the best or the worst value specified. When a hierarchical model is used, the average normalized weights $\bar{Z}^{*}$ are determined for the main attributes (criteria) of the groups (Level One), and the normalized weights $\bar{Q}$ are found for each attribute (criterion) or sub-attribute (subcriterion) (Level Two) (Kaya \& Kahraman, 2014; Wang, Yu, Yang, Lin, Lee, \& Cheng, 2013; Gudienè, Banaitis, Podvezko, \& Banaitienè, 2014).

The average normalized weights $\bar{Z}^{*}$ of the groups of criteria (A, B, C and D) and normalized weights $\bar{Q}$ of each criterion of each group are directly found by using the AHP method (Saaty, 1980). These weights can also be calculated based on the ranks by applying the respective methods (Kendall \& Gibbons, 1990; Podvezko \& Sivilevicius, 2013).

Three categories of people are involved in the process of transportation. They include passengers $(P)$, the service staff of the train (ST), and the administration staff of the jointstock company (AS). The aims of these people, as well as their responsibilities, qualification, ways of achieving benefit and their dependence on the performance of the railway company, differ considerably. Therefore, the significances of particular criteria and their groups, describing the QTT assigned by respondents $(P)$ and experts (ST and AS), which are determined by applying the AHP approach, differ to some extent. 


\section{THE CRITERIA DESCRIBING RAILWAY TRIP QUALITY}

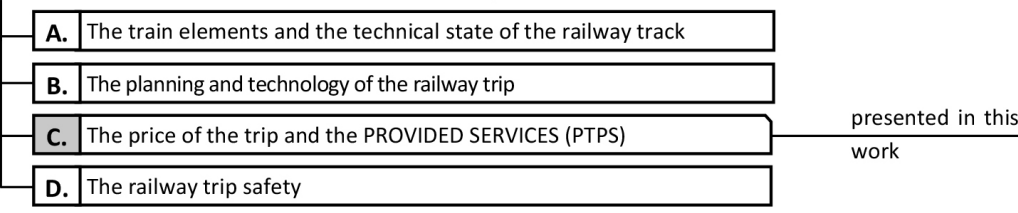

\begin{tabular}{|c|c|}
\hline C1. & Price of a ticket \\
\hline C2. & Price of meals served in the dining-car and their quality \\
\hline C3. & Price of newspapers and magazines \\
\hline C4. & Price of health insurance card valid abroad \\
\hline C5. & Price of visa \\
\hline C6. & $\begin{array}{l}\text { Delivery of meals (included into the ticket price) to passengers travelling in the } \\
\text { first-class double compartment }\end{array}$ \\
\hline
\end{tabular}

In the present work, 49 QTT criteria, belonging to four various groups $(A, B, C, D)$ (Fig. 1), were considered. Group $A$ includes 16 criteria (Maskeliūnaitè \& Sivilevičius, 2014; Sivilevičius \& Maskeliūnaitè, 2014), Group B has 19 criteria (Sivilevičius, Maskeliūnaitè, Petkevičienè, \& Petkevičius, 2012), Group C includes 6 criteria (considered in this work) and group $D$ includes 8 criteria (analysed in the paper prepared for publication). The average weights of the criteria in each group were determined by using the AHP method.

The weights of six criteria, belonging to group $\mathrm{C}$ and describing the PTPS by international train, were obtained from the survey of experts, when three categories of respondents, such as passengers $(P)$ and experts, including the service staff of the train (ST) and the administration staff (AS) of the joint-stock company 'Lithuanian Railways', provided their estimates. The mean weight, $\bar{Z}_{C}^{*}$, shows the significance of the criteria of group $C$ (with a different number of the respondents and experts in each category). This weight was calculated as follows:

$$
\bar{Z}_{C}^{*}=\frac{Z_{C, P} \cdot n_{P}+Z_{C, S T} \cdot n_{S T}+Z_{C, A S} \cdot n_{A S}}{n_{P}+n_{S T}+n_{A S}},
$$

where $Z_{C, P}, Z_{C, S T}, Z_{C, A S}$ are the weights, assigned to the criteria of group $C$ by the respondents (experts) of categories P, ST, AS; $n_{P}, n_{S T}, n_{A S}$ denote the numbers of the respondents $(P)$ and experts (ST, AS).

The significance estimates (in weights) provided to the criteria referring to all groups of passengers $(P)$, service staff (ST) and the administration staff (AS) of the train are presented in Tab. 1.

The quality of passenger transportation by any train can be determined only roughly, subjectively and intuitively. Therefore, to evaluate it more accurately, a qualitative method and the comprehensive quality index (CQI) $K$, allowing for the quality of travel on a particular route to be expressed by a single number, were developed $\left(K=K_{A}+K_{B}+K_{C}+\right.$ $+K_{D}, K=0 \div 1$ ). The model for calculating the criteria, describing the PTPS, based on the mean weight $\bar{Z}_{C}^{*}$ and the mean weight of each criterion $\bar{Q}_{C j}$ (which give the estimates of the significance of group $\mathrm{C}$ criteria elicited from all 


\section{Business Administration and Management}

Tab. 1:

The significances (weights) of the criteria of groups A, B, C and D, describing travel by train (Maskeliūnaitè \& Sivilevičius, 2012)

\begin{tabular}{|c|c|c|c|c|c|}
\hline \multirow{2}{*}{$\begin{array}{l}\text { Category of respondents } \\
\text { and experts }\end{array}$} & \multirow{2}{*}{$\begin{array}{l}\text { Number of questi- } \\
\text { onnaires, } \\
n \text { (pairwise } \\
\text { comparison matrix) }\end{array}$} & \multicolumn{4}{|c|}{ Weights $Z$ of criteria groups } \\
\hline & & A & B & C & D \\
\hline Passengers $(\mathrm{P})$ & $n_{p}=21$ & 0.2143 & 0.2619 & 0.2714 & 0.2524 \\
\hline Service staff of the train (ST) & $n_{S T}=20$ & 0.2800 & 0.1900 & 0.1950 & 0.3350 \\
\hline $\begin{array}{l}\text { Administration staff of 'Lithuanian } \\
\text { Railways' (AS) }\end{array}$ & $n_{A S}=9$ & 0.1444 & 0.2333 & 0.3667 & 0.2556 \\
\hline $\begin{array}{l}\text { The average estimate value of all } \\
\text { respondents and experts in all groups } \\
\text { of criteria }\end{array}$ & $\Sigma n=50$ & 0.2280 & 0.2280 & 0.2580 & 0.2860 \\
\hline
\end{tabular}

Source: own

three categories of respondents and experts), was described by the equation:

$$
\begin{aligned}
& K_{C}=\bar{Z}_{C}^{*} \cdot \sum_{j=1}^{m}\left(\bar{Q}_{C j} \cdot x_{C j}\right)= \\
& =\bar{Z}_{C}^{*}\left(\bar{Q}_{C 1} \cdot x_{C 1}+\bar{Q}_{C 2} \cdot x_{C 2}+\ldots+\right. \\
& \left.+\bar{Q}_{C 6} \cdot x_{C 6}\right)
\end{aligned}
$$

where $K_{C}$ is the component of the CQI of the international train, depending on the PTPS (and ranging from 0 to $\left.\bar{Z}_{C}^{*}\right) ; \bar{Z}_{C}^{*}$ is the mean weight, showing the estimates of the respondents and experts assigned to the weights of the criteria of group $C ; \bar{Q}_{C 1}, \ldots, \bar{Q}_{C m}$ (Fig. 2) denote the mean weight values of $j$-th criterion of group C $(j=1,2, \ldots, m)$ determined by the expert evaluation method; $x_{c 1}, \ldots, x_{c m}$ are the variables of $j$-th criterion of group $C(j=1,2, \ldots, m)$, whose estimates are used for determining the real criterion value, ranging from 0 to 1 .

To calculate the CQI, evaluating the significance of the trip by an international train, depending on the PTPS, the variables of any criterion in the set $x_{C 1}, \ldots, x_{C 6}$, serving as a basis for calculating the real criterion value ranging from 0 to 1 , should be determined.

\section{Fig. 2: The mean weight $\bar{Q}_{C j}$ of j-th criterion of group C determined by the AHP method}

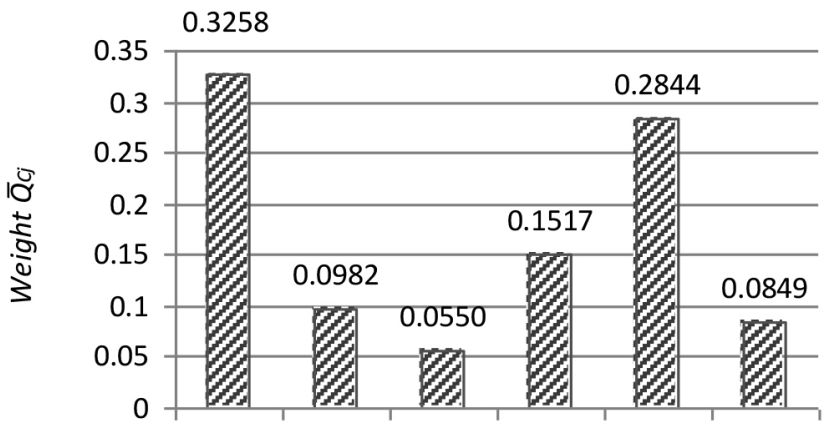

$\begin{array}{llllll}\mathrm{C} 1 & \mathrm{C} 2 & \mathrm{C} 3 & \mathrm{C} 4 & \mathrm{C} 5 & \mathrm{C} 6\end{array}$

Number of criteria group $\mathrm{C}$ 


\subsection{Price of a Ticket}

When the highest $\left(P T_{\max }\right)$ and the lowest $\left(P T_{\min }\right)$ prices of the ticket to a sleeping (S), compartment $(\mathrm{C})$ or luxury $(\mathrm{L})$ car, are known, the value of the CQI component, depending on the price, $K_{C}$, of the trip by train, the product of $\bar{Q}_{C 1} \cdot x_{C 1}$ and the variable, $x_{C 1}$, which shows the influence of the ticket price on the quality of the trip, can be calculated by the equation:

$$
x_{C 1}=\frac{\sum_{y=1}^{3} n_{y} \cdot\left(1-\frac{P T_{f}-P T_{m i n}}{P T_{\max }-P T_{\min }}\right)}{n_{\text {car }}},
$$

where $x_{C 1}$ is the variable of the first criterion of group C; $n_{y}$ is the number of cars of $y$-th category (S, C or L) in the train; $P T_{f}, P T_{\text {min }}$ and $P T_{\max }$ denote the factual, the lowest and the highest ticket price, respectively, for a car of $y$-th category, $€ ; n_{c a r}$ is the number of cars in the train $\left(n_{c a r}=n_{S}+n_{C}+n_{L}\right)$.

The analysis of the prices of the tickets sold in Lithuania and Russia has shown that the same tickets are more expensive in Russia. The prices of the tickets bought in Lithuania and Russia in September 2014 for four trips by the train 'Moscow-Vilnius' are determined. One can see that the average difference in prices makes $19 \%$. It is difficult to understand, why there is such a great difference between the tickets to the same route bought in Lithuania and in Russia.

\subsection{Price of Meals Served in the Dining- Car and Their Quality}

The dishes served in the dining car can be evaluated based on the four criteria as follows:

- price of meals (PM);

- course (dish) quality (CQ);

- assortment abundance (AA);

- course change cycle (CCC).

In the absence of the data on passengers' estimates of the significance of each of these criteria, the weight 1 . The weight is taken the same whilst variable is calculated as follows:

$$
x_{C 2}=\frac{x_{C 2, P M}+x_{C 2, C Q}+x_{C 2, A A}+x_{C 2, C C C}}{4},
$$

where $x_{C 2}$ is the variable of the second criterion of group $\mathrm{C} ; x_{C 2, P M}$ is the variable of the second criterion of group $\mathrm{C}$, showing the price of meals; $x_{C 2, C Q}$, is the variable of the second criterion of group $\mathrm{C}$, showing the course (dish) quality; $x_{C 2, A A}$ is the variable of the second criterion of group $\mathrm{C}$, showing the assortment abundance; $x_{C 2, c c c}$ is the variable of the second criterion of group $\mathrm{C}$, showing the course change cycle.

More accurate evaluation of the significance of these criteria can be performed by conducting a questionnaire survey. The variable summand of the CQI component, $K_{c}$, determining the price of meals (PM), their quality (CQ), the assortment abundance (AA) and the course change cycle (CCC), is calculated by the equation:

$$
\begin{aligned}
& x_{C 2}=\omega_{P M} \cdot x_{C 2, P M}+\omega_{C Q} x_{C 2, C Q}+ \\
& +\omega_{A A} x_{C 2, A A}+\omega_{C C C} x_{C 2, C C C}
\end{aligned}
$$

where $\omega_{P M}$ is the weight of the meal price; $\omega_{C Q}$ is the weight of the dish quality; $\omega_{A A}$ is the weight of the assortment abundance; $\omega_{C C C}$ is the weight of the course change cycle.

In this study, the weights, $\omega_{P M}, \omega_{C Q}, \omega_{A A}$ and $\omega_{c c c}$, of the criteria, describing the services provided in the dining car, were determined based on the judgements of 12 passengers about the provided services $(i=1,2, \ldots, n)$. They gave the ranks $R_{i j}$ to the considered four criteria $(j=1,2, \ldots, m)$. The number of the respondents, $n=12$, was three times as large as the number of the criteria describing services, $m=4$, and, therefore, was sufficient for evaluation.

The estimate made by the group of respondents (passengers) is taken as the solution to the problem (or its result) only if it is consistent. This estimate, expressed by the coefficient $W$ (Kendall's coefficient of concordance), was calculated by the equation:

$$
W=\frac{12 S}{n^{2}\left(m^{3}-m\right)}=\frac{12 \cdot 618}{12^{2}\left(4^{3}-4\right)}=0.858
$$

where $S$ is the sum of the squared deviations of the sum of ranks $\sum_{i=1}^{n} R_{i j}$ (assigned by each of 4 passengers to the services provided in the dining car of the train) from the mean rank value $\bar{R}=\frac{n(m+1)}{2}$ :

$$
\begin{aligned}
& S=\sum_{j=1}^{m}\left[\sum_{i=1}^{n} R_{i j}-\frac{1}{2} n(m+1)\right]^{2}= \\
& =-2^{2}-17^{2}+1^{2}+324^{2}=618
\end{aligned}
$$




\section{Business Administration and Management}

The Pearson chi-squared test was used to determine if the judgements of twelve respondents were in agreement:

$$
\chi^{2}=n(m-1) \cdot W=12(4-1) \cdot 0.858=30.89 .
$$

The number of the degrees of freedom $v=m-1=4-1=3$ was calculated for the number of respondents, $n=12$, and the number of the compared quality factors, $m=4$, while a relatively high significance level, $\alpha=0.01$, was selected. The critical value, $\chi_{v, \alpha}^{2}$, corresponding to the number of degrees of freedom and the selected significance level, $\chi_{v, \alpha}^{2}$, equal to 11.34 (which is much smaller than the calculated value $\left(\chi^{2}=30.89\right)$, was selected from the statistical Appendix Tab. 8 (Kendall \& Gibbons, 1990).

The lowest value of the concordance coefficient, $W_{\min }$, was calculated from Eq. (9), with the significance level $\alpha=0.01$ and the number of the degrees of freedom $v=3$. Therefore, it could be stated that the respondents' estimates were still in concordance:

$$
W_{\text {min }}=\frac{\chi_{v, \alpha}^{2}}{n(m-1)}=\frac{11.34}{12(4-1)}=0.315 \ll 0.858
$$

The significances (weights) of the criteria, describing services provided to passengers in the dining car of the train, were determined based on the method of the average rank transformation into weight (ARTIW) developed by the author (Sivilevičius, 2011):

$$
\omega_{j}=\frac{(m+1)-\bar{R}_{j}}{\sum_{j=1}^{m} \bar{R}_{j}} .
$$

The weights of these criteria, which were calculated by Eq. (10), based on the average ranks $\bar{R}_{j}$, assigned by 12 respondents to four criteria describing the services provided in the dining car, are given in Tab. 2.

The influence of the dish price on the quality of the trip by train can be expressed by Eq. (11), showing the variable value of this criterion:

$$
x_{C 2, P M}=\frac{P M_{\text {min }}}{P M_{\text {average }}}=\frac{P M_{\text {min }}}{\sum_{d=1}^{n_{C}}\left(\frac{P M_{d} \cdot F_{d}}{F}\right)},
$$

where $P M_{\min }$ is the lowest price of the dish served in the dining car of the train, $€ ; P M_{\text {average }}$ is the average price of the dish, $€ ; n_{C}$ is the number of the categories of dishes served in the dining $\operatorname{car}\left(d=1,2, \ldots, n_{c}\right) ; P M_{d}$ is the price of the dish of $d$-th category, $€ ; F_{d}$ is the rate of the $d$-th dish ordering, i.e. the number of the served (sold) dishes of this kind; $F$ is the rate of ordering (serving) the dishes of all categories offered in the dining car, i.e. the total number of all served dishes, $\left(F=F_{1}+F_{2}+\ldots+F_{n_{c}}\right)$.

The quality of the dishes served in the dining car of the train can be expressed by Eq. (11), when the variable is calculated:

$$
x_{C 2, C Q}=\frac{P_{C Q 0} \cdot n_{0}+P_{C Q 1} \cdot n_{1}+\ldots+P_{C Q 4} \cdot n_{4}}{4 \cdot\left(n_{0}+n_{1}+\ldots+n_{4}\right)},
$$

where $x_{C 2, C Q}$ is the variable showing the dish quality; $P_{C Q 0}, P_{C Q 1} \ldots P_{C Q 4}$ denote the estimate of a dish expressed in points as follows: $P_{C Q_{0}}=0$ (very poor), $P_{C Q_{1}}=1$ (poor), $P_{C Q_{2}}=2$ (satisfactory), $P_{\mathrm{CQ}_{3}}=3$ (good) and $P_{\mathrm{CQ}_{4}}=4$ (very good, the highest possible estimate in points); $n_{0}, n_{1}, \ldots, n_{4}$ denote the number of points assigned by the respondents, evaluating the dishes $\left(n_{0}+n_{1}+n_{2}+n_{3}+n_{4}=n\right.$ denotes the number of all respondents, who estimated the quality of the served dishes).

The assortment abundance was described by the ratio of the real number of dishes available in the dining car in the investigated

Tab. 2:

The average ranks, $\bar{R}_{j}$, awarded by passengers to the quality of services provided in the dining car, and their weights, $\omega_{j}$

\begin{tabular}{l|c|c|c|c}
\multirow{2}{*}{$\begin{array}{c}\text { Significance } \\
\text { (weight) }\end{array}$} & \multicolumn{4}{|c}{ The criteria, describing the quality of services provided in the dining car } \\
\cline { 2 - 5 } & PM & CQ & AA & CCC \\
\hline $\bar{R}_{j}$ & 2.333 & 1.083 & 2.583 & 4.000 \\
\hline$\omega_{j}$ & 0.267 & 0.391 & 0.242 & 0.100 \\
\hline Priority order & 2 & 1 & 3 & 4 \\
\hline
\end{tabular}


period, $n_{A A f}$, to the largest amount of dishes ever offered in international trains, $n_{\text {AAmax }}$ :

$$
x_{C 2, A A}=\frac{n_{A A f}}{n_{A A \max }},
$$

where $x_{C 2, A A}$ is the variable of the second criterion of group $C$, determining the assortment abundance; $n_{A A f}$ is the factual number of dishes offered in the dining car during the investigated trip; $n_{\text {AAmax }}$ is the maximum number of dishes ever offered in the dining car.

The course change cycle was evaluated in points as follows: 0 means that dishes are not changed, 1 denotes that dishes are changed once a month or more often, 2 means that dishes are changed once in two weeks, 3 denotes that dishes are changed once a week, and 4 means that dishes are changed in every trip. The cycle was expressed by the ratio of the estimate in points given to the real course change cycle, $\mathrm{CCC}_{f}$, and the estimate in points given to the shortest cycle, $C C C_{\max }$ :

$$
x_{C 2, C C C}=\frac{\mathrm{CCC}_{f}}{\mathrm{CCC}_{\max }},
$$

where $C_{C C}$ denotes the real estimate in points awarded to the course change cycle; $C C C_{\max }$ is the highest estimate (4 points) given to the cycle.

\subsection{Price of Newspapers and Magazines}

The price of newspapers and magazines sold in the train was evaluated in points as follows: 0 means that the prices of newspapers and magazines offered in the train are higher than their prices in the news-stalls, 1 means that the prices of newspapers and magazines offered in the train and their prices in news-stalls are the same, 2 shows that the prices of newspapers and magazines offered in the train are lower than their prices in the news-stalls. The summand of the CQI component, $K_{c}$, assessing the price of newspapers and magazines in the train, was calculated by the equation:

$$
x_{C 3}=\frac{N M_{f}}{N M_{\max }},
$$

where $x_{C 3}$ is the variable of the third criterion of group $\mathrm{C}$; $N M_{f}$ shows the estimate of the criterion describing the price of newspapers and magazines offered in the train in points
$(0,1$ or 2$) ; N M_{\max }$ is the highest possible estimate (2 points) given to the price of newspapers and magazines in the train.

\subsection{Price of the Health Insurance Card Valid Abroad}

Health insurance is required in the case, when a passenger of the train requires medical help because of an acute disease. The required medical help is usually provided either in an outpatient department or in a hospital abroad. The summand of the CQI component, $K_{C}$, assessing health insurance price abroad, was calculated by the equation:

$$
x_{C 4}=\left(1-\frac{P P_{f}-P P_{\min }}{P P_{\max }-P P_{\min }}\right),
$$

where $x_{C 4}$ is the variable of the fourth criterion of group C; $P P_{f}, P P_{\min }, P P_{\max }$ denote the real, the lowest and the highest price of health insurance abroad.

\subsection{Price of Visa}

The summand of the CQI component $K_{c}$, determining the highest price, $P V_{\max }$, and the lowest price, $P V_{\min }$, of a visa in any country, to which (or through which) the train goes, was calculated by the equation:

$$
x_{C 5}=\frac{\sum_{V=1}^{n_{V}} \cdot\left(1-\frac{P V_{f}-P V_{\text {min }}}{P V_{\max }-P V_{\min }}\right)_{V}}{n_{V}},
$$

where $x_{C 5}$ is the variable of the fifth criterion of group $\mathrm{C} ; n_{V}$ is the number of visas required for the trip, $\left(V=1,2, \ldots, n_{V}\right) ; P V_{f}, P V_{\min }, P V_{\max }$ denote the real, the lowest and the highest prices of $V$-th visa's price.

\subsection{Delivery of Meals (Included in the Ticket Price) to Passengers Travelling in the First-Class Double Compartment}

The price of the delivery of meals included in the ticket price to passengers was calculated in points. In this case, 0 means that the delivery of meals is not included in the ticket price and, therefore, this service is not provided to the passengers in the car; 1 denotes that the delivery of supper or breakfast is included in the ticket 
price; 2 means that the delivery of both breakfast and supper are included in the ticket price. The summand of CQI component $K_{c}$, determining the price of meal delivery included in the ticket for passengers travelling in the first-class double compartment, was calculated by the equation:

$$
x_{C 6}=\frac{D M_{f}}{D M_{\max }}
$$

where $x_{C 6}$ is the variable of the sixth criterion of group C; $D M_{f}$ denotes the real estimate (in points) of the delivery of meals (or its absence), included (not included) in the ticket price of the passengers travelling in the first-class double compartment (0,1 or 2 points); $D M_{\max }$ is the highest possible estimate (2 points) of the delivery of meals included in the ticket price.

The index $K_{c}$, describing the criteria associated with the price of the trip by an international train and the provided services, was calculated as follows:

$$
\begin{aligned}
& K_{C}=\bar{Z}_{C}^{*} \cdot\left(\bar{Q}_{C 1} \cdot \frac{\sum_{y=1}^{3} n_{y} \cdot\left(1-\frac{P T_{f}-P T_{\text {min }}}{P T_{\max }-P T_{\min }}\right)_{y}}{n_{C a r}}+\bar{Q}_{C 2} \cdot\left(\omega_{P M} \cdot x_{C 2, P M}+\omega_{C Q} \cdot x_{C 2, C Q}+\omega_{A A} \cdot x_{C 2, A A}+\omega_{C C C} \cdot\right.\right. \\
& \left.\left.\cdot x_{C 2, C C C}\right)+\bar{Q}_{C 3} \cdot \frac{N M_{f}}{N M_{\max }}+\bar{Q}_{C 4} \cdot\left(1-\frac{P P_{f}-P P_{\min }}{P P_{\max }-P P_{\min }}\right)+\bar{Q}_{C 5} \cdot \frac{\sum_{v=1}^{n_{V}} \cdot\left(1-\frac{P V_{f}-P V_{\min }}{P V_{\max }-P V_{\min }}\right)_{V}}{n_{V}}+\bar{Q}_{C 6} \cdot \frac{D M_{f}}{D M_{\max }}\right)
\end{aligned}
$$

Due to the application of the considered model, as well as the real research data and the allowable or best values of each criterion, the significances of the criteria of group $C$ for evaluating the quality of passenger transportation by train could be described by a single value.

\section{Practical Application of the Model}

Using the equations suggested in the paper for determining CQI components (six criteria), the authors could calculate their significances based on the real data taken from the surveys (on the quality of dishes) and other reliable sources. The testing was performed in the train 'Vilnius-Moscow'.

\subsection{The Calculated Price of a Ticket}

Basic fares for local transportation services provided by $A B$ 'Lietuvos geležinkeliai' were determined, depending on the class of services offered in passenger cars (2nd or 3rd class) and the speed of the train (fast or ordinary trains).
The price of passenger transportation does not depend on the type of traction and railway lines. The train Vilnius-Moscow has one sleeping (S) car $\left(n_{S}=1\right)$, four compartment $(C)$ cars $\left(n_{C}=4\right)$ and one luxury $(L)$ car $\left(n_{L}=1\right)$. The indexation coefficients were determined for basic fares of passenger transportation (which are fixed for Lithuanian and Byelorussian railways and vary, depending on the season, for Russian railway lines). Seeking higher occupancy of passenger cars in various days of the week, as well as higher profit from the trips by the 'LG' trains, special coefficients (depending on the days of the week) were introduced for fares for travelling in various berths in the cars. The upper berth fare is higher than that of a lower berth. The lowest fares are on May 8-9, while the highest fares are on April 28-29, June 8-12, July 13, November 2-5 and December 29-30.

The train has six passenger cars of $S, C$ and $\mathrm{L}$ categories. To calculate the CQI summand, the expanded Eq. (3), which is given below, was used for various car categories of the train Vilnius-Moscow:

$$
x_{C 1}=\frac{n_{S} \cdot\left(1-\frac{P T_{f S}-P T_{\min S}}{P T_{\max S}-P T_{\min S}}\right)+n_{C} \cdot\left(1-\frac{P T_{f C}-P T_{\min C}}{P T_{\max C}-P T_{\min C}}\right)+n_{L} \cdot\left(1-\frac{P T_{f L}-P T_{\min L}}{P T_{\max L}-P T_{\min L}}\right)}{n_{c a r}},
$$


where $n_{c a r}$ is the number of cars in the train $\left(n_{\text {car }}=n_{S}+n_{C}+n_{L}\right) ; n_{S}$ is the number of ordinary second-class sleepers, $n_{C}$ is the number of the second-class 4-berth compartment cars and $n_{L}$ is the number of the first-class luxury two-berth cars; $P T_{f S}, P T_{\min S}, P T_{\max }$ denote the regular, the lowest and the highest fare in the car of $\mathrm{S}$ category, $€ ; \mathrm{PT}_{f C}, P T_{\min c}, P T_{\max }$ denote the regular, the lowest and the highest fare in the car of $C$ category, $€ ; P T_{f L}, P T_{\min L}, P T_{\max L}$ denote the factual, the lowest and the highest fare in the car of $L$ category, $€$, respectively.

The fares for travelling in the cars of $S$ and C categories used in Eq. (20) were assumed to be the mean values of the fares for travelling in the lower and upper berths, $€$, while for the cars of $L$ category, only the fare for travelling in a lower berth, which was the same in this case, was considered. The fares varied depending on particular seasons. Thus, on May 11, 2012, regular fares were used, while on May 9 they were the lowest, and, on June 8 , the fares were the highest. The value of $x_{C 1}=0.287$ was obtained for the train Vilnius-Moscow.

\subsection{The Calculated Price of Meals Served in the Dining-Car and Their Quality}

Eqs. (11)-(14) were used for calculating the CQI $x_{\mathrm{C} 2}$ summand. The price of the meal served in the dining-car was calculated by Eq. (11). The lowest price of a dish was $\mathrm{PM}_{\text {min }}=1.16 €$. Ten various dishes were served in the dining-car $\left(n_{C}=10\right)$, while their prices $\left(\mathrm{PM}_{\mathrm{d}}\right)$ were as follows. The total number of the served dishes was $F=97$. The variable of the quality criterion, $\mathrm{C}_{2}$, was $x_{C 2, P M}=0.339$.

The oral survey of the passengers of the train was made (by the train head), which had shown very positive evaluation (3 points) of the quality of the dishes served by the majority of passengers. Eq. (12) was used for evaluating the quality of meals (dishes). For $P_{C Q O}=0$, $P_{\mathrm{CQ1}}=1, P_{\mathrm{CQ} 2}=2, P_{\mathrm{CQ} 3}=3, P_{\mathrm{CQ} 4}=4$ and $n_{0}=0$, $n_{1}=5, n_{2}=3, n_{3}=23, n_{4}=29,\left(n_{0}+n_{1}+\ldots+\right.$ $\left.n_{4}=60\right)$, it was found that $x_{C 2, C Q}=0.817$. Eq. (13) was used to assess the assortment abundance. When $n_{A A f}=14$ and $n_{\text {AAmax }}=24, x_{C 2, A A}=0.583$. The course change cycle was evaluated by Eq. (14) as follows: when $C C C_{f}=1$ and $C C C_{\max }=4, x_{C 2, C C C}=0.25$. For the real data, $x_{C 2}=0.576$ Eq. (5)).

\subsection{The Calculated Price of Newspapers and Magazines}

The prices of newspapers and magazines in the train did not differ from those in the news stalls. The CQI summand was calculated by Eq. (15), and, for a general case, $x_{C 3}=0.50$, was found.

\subsection{The Calculated Price of the Health Insurance Card Valid Abroad}

Lithuanian citizens going to Russia (e.g. by the train Vilnius-Moscow) should have health insurance valid abroad. The insurance is valid for 1-3 days and price $2.32 €$, while the lowest price of the required medical service guaranteed by it is $1.74 €$ and the highest price is $3.48 €$. The variable summand, $x_{C 4}$, of the CQI component was calculated by Eq. (16), which yielded $x_{C 4}=0.667$.

\subsection{The Calculated Price of a Visa}

Lithuanian passengers travelling to Russia by the train Vilnius-Moscow should have two visas, including a transit visa to Byelorussia and a visa to Russia. Visas can be of various types (e.g. visas for tourism and commerce) and can be valid for a specified period of time (e.g. for one, two or more visits). Let us assume that a passenger needs a tourist visa for one visit only (the period of up to 30 days) to Russia and a transit Byelorussian visa for one visit. It usually takes about 6-7 working days to get these visas. Eq. (17) was used to calculate the variable summand, $x_{C 5}$, of CQI, which yielded $x_{C 5}=0.804$ (for the real data).

\subsection{The Calculated Delivery of Meals (Included into the Ticket Price) to Passengers Travelling in the First-Class Double Compartment}

At present, breakfast and supper are included only in the price of the tickets to the L category passenger cars of the international trains of 'Lietuvos geležinkeliai'. To evaluate the quality of the delivery of meals (the variable summand, $x_{C 6}$, of CQI) included in the ticket price, Eq. (18) was used, which yielded $x_{C 6}=1$.

\subsection{The Value of the CQI Component, Depending on the PTPS}

The quality of the items and services described by the criteria of group $C$ and the respective $x_{C j}$ value, based on the real data, are presented in 
Tab. 3: The quality level described by the criteria of group $C$ and the respective value of variable $x_{C j}$ based on real data

\begin{tabular}{l|l|c}
$\begin{array}{c}\text { Variables } x_{C j} \text { of the criteria } \\
\text { of group } C \text { and the number } \\
\text { of the calculation equation }\end{array}$ & \multicolumn{1}{|c}{ The value of the component } & $\begin{array}{c}\text { The calculated } \\
\text { value } x_{C j}\end{array}$ \\
\hline$x_{C 1}(3)$ and (20) & $\begin{array}{l}P T_{f S}=69.87 ; P T_{\min S}=58.94 P T_{\max S}=74.24 ; \\
P T_{f C}=101.86 P T_{\min C}=81.08 ; P T_{\max C}=110.17 \\
P T_{f L}=196.21 ; P T_{\min L}=154.67 P T_{\max L}=212.81 ; \\
n_{S}=1 ; n_{c}=4 ; n_{L}=1\end{array}$ & 0.287 \\
\hline$x_{C 2}(5),(11),(12),(13),(14)$ & $\begin{array}{l}x_{C 2, P M}=0.339 ; x_{C 2, C Q}=0.817 ; x_{C 2, A A}=0.583 \\
x_{C 2, C C C}=0.25\end{array}$ & 0.576 \\
\hline$x_{C 3}(15)$ & $N M_{f}=1 ; N M_{\max }=2$ & 0.500 \\
\hline$x_{C 4}(16)$ & $P P_{f}=2.32 ; P P_{\min }=1.74 ; P P_{\max }=3.48$ & 0.667 \\
\hline$x_{C 5}(17)$ & $\begin{array}{l}P V_{f B}=20.27 ; P V_{\min B}=18.83 P V_{\max B}=24.62 ; \\
P V_{f R}=63.72 P V_{\min R}=57.92 ;\end{array}$ & 0.804 \\
\hline$x_{C 6}(18)$ & $P V_{\max R}=98.47 ; n_{v}=2$ & 1 \\
\hline
\end{tabular}

Tab. 3. The quality level shown by the estimate of the variable $x_{C j}$, based on the highest values of the real data, was equal to 1 , but based on the average values, it was equal to 0.5 .

The index $K_{C}$ of the criteria describing the PTPS was calculated by Eq. (19) as follows:

$K_{C}=0.2580 \times(0.3258 \times 0.287+0.0982 \times$

$\times 0.576+0.0550 \times 0.50+0.1517 \times 0.667+$

$+0.2844 \times 0.804+0.0849 \times 1)=0.153$.

The index referring to the criteria, describing the price of the trip by international train and the provided services, was found to be $K_{C}=0.153$. It is approximately 40 percent less than the maximum (indicating the best quality) $K_{C \max }=0.2580$. Average quality will be when $K_{C}=\frac{1}{2} \cdot \bar{Z}_{C}^{*}=\frac{1}{2} \cdot 0.258=0.129$. The poor quality will be when $K_{C}=0$, and excellent quality $K_{C}=\bar{Z}_{C}^{*}=0.258$.

The influence of the criteria of groups $A$ and $B$ on the CQI $K$ was evaluated by using the mathematical models, which yielded $K_{A}=0.1341$ (Maskeliūnaitè \& Sivilevičius, 2014; Sivilevičius \& Maskeliūnaitè, 2014) and $K_{B}=0.099$ (Sivilevičius, Maskeliūnaitè, Petkevičienè, \& Petkevičius, 2012), respectivly. The influence of the criteria of the groups $D$ on CQI $K$ can be evaluated by another additive model, which will be described in further publications.

According to this methodology, the calculated comprehensive quality index characterizing a trip by an international train can be used by the railway passenger transport companies' decision makers determining the suitability of individual trains to carry-out its activities.

\section{Conclusions}

The influence of the criteria of four groups, describing passenger transportation by the considered international train on its quality evaluation, differs considerably. Based on using the analytic hierarchy process (AHP) and the data obtained in the questionnaire survey of 50 passengers, the service staff of the train and the administration staff of the jointstock company 'LG', the normalized weights of the criteria of four groups $(A, B, C, D)$ and those of the particular criteria of each group were determined. The largest average weight was determined for the criteria of group $D$, describing the railway trip safety $(0.286)$, while a smaller weight was obtained for the criteria of group $\mathrm{C}$, describing the price of the trip and the provided services $(0.258)$. The smallest weights were found for the criteria of groups $A$ and $B$, describing the elements of the train and the technical state of the railway track, as well as the organization and technology of the railway trip (0.228). The passengers and the administration staff of the train assessed the criteria of group $\mathrm{C}$ as most important $(0.271$ and 0.367 , respectively). 
The normalized average weights of six criteria of group $\mathrm{C}$ also differed considerably. Thus, the respondents of all three categories, including passengers and experts (the service staff of the train and the administration staff of the joint-stock company 'LG'), evaluated the criteria, such as the ticket price $(0.3258)$ and the price of a visa (0.2844) as the most important criteria considered. The criteria of the price of newspapers and magazines (0.0551), as well as the delivery of meals (included into the ticket price), were evaluated by the respondents (particularly, by the passengers travelling in the first-class double compartments) as the least important criteria (0.0849).

The price of meals served in the dining-car and their quality was the fourth most significant criterion of group $C$ (with the weight of 0.098). It consisted of the price of meals (PM), course (dish) quality (CQ), assortment abundance (AA) and the course change cycle (CCC). The Kendall rank correlation method and the equations suggested by the authors yielded the following weights of the criteria, describing the quality of services provided in the diningcar of the train (which were obtained based on the ranks) (Tab. 2): PM (0.267), CQ (0.391), AA (0.242) and CCC (0.100).

The accuracy of the calculated quality index $K_{c}$ of the mathematical model (Eq. 19), used by the authors to express the weights of the criteria (group C), describing the PTPS in a single value, was checked based on the real data on the trip by the train 'Vilnius-Moscow'. The calculated coefficient, $K_{c}$, referring to this group of criteria, was equal to 0.153 . This value is between 0 (the lowest quality) and 0.258 (the highest quality) and makes almost $60 \%$ of the ideal value for the criteria of group $\mathrm{C}$. The results obtained in the study allow the authors to conclude that the quality of the trip by the considered train is higher than the average quality of the trips by train.

\section{References}

Aghdaie, M. H., Hashemkhani Zolfani, S., \& Zavadskas, E. K. (2013). Decision making in machine tool selection: an integrated approach with SWARA and CORPAS-G methods. Inzinerine Ekonomika - Engineering Economics, 24(1), 5-17. https://dx.doi.org/10. $\mathrm{s}+\mathrm{SS} / \mathrm{j01}$.ee.24.1.2822.

Albaladejo, I., \& González-Martínez, M. (2018). A nonlinear dynamic model for international tourism demand on the Spanish Mediterranean coasts. E\&M Ekonomie a Management, 21(4), 65-78. https://doi. org/10.15240/tul/001/2018-4-005.

Allen, J., Eboli, L., Mazzulla, G., \& Ortúzar, J. D. (2018). Effect of critical incidents on public transport satisfaction and loyalty: an Ordinal Probit SEM-MIMIC approach. Transportation. https://doi.org/10.1007/s11116-018-9921-4.

Avdovskiy, A. A., Badaev, A. S., Belov, K. A., etal. (2013). Organizatsiya zheleznodorozhnykh passazhirskikh perevozok. Moskva: Akademiya.

Bajćetić, S., Tica, S., Živanović, P., Milovanović, B., \& Dorojević, A. (2018). Analysis of public transport users' satisfaction using quality function deployment: Belgrade case study. Transport, 33(3), 609-618. https://doi.org/10.3846/transport.2018.1570.

Batley, R., Dargay, J., \& Wardman, M. (2011). The impact of lateness and reliability on passenger rail demand. Transportation Research Part E: Logistics and Transportation Review, 47(1), 61-72. https://doi.org/10.1016/j. tre.2010.07.004.

Belov, I. V., Tereshina, N. P., Galaburda, V. G., et al. (2001). Ekonomika zheleznodorozhnogo transporta. Moskva: Marshrut.

Börjesson, M. (2014). Forecasting demand for high speed rail. Transportation Research Part A: Policy and Practice, 70, 81-92. https://dx.doi.org/10.1016/j.tra.2014.10.010.

Bureika, G., Bekintis, G., Liudvinavičius, L., \& Vaičiūnas, G. (2013). Applying analytic hierarchy process to assess traffic safety risk of railway infrastructure. Maintenance and Reliability = Eksploatacja I Niezawodność, 15(4), 376-383.

Chen, S., Leng, Y., Mao, B., \& Liu, S. (2014). Integrated weight-based multi-criteria evaluation on transfer in large transport terminals: A case study of the Beijing South railway station. Transportation Research Part A: Policy and Practice, 66, 13-26. https://dx.doi. org/10.1016/j.tra.2014.04.015.

Cheng, M.-Y., Su, C.-W., Tsai, M.-H., \& Lin, K.-S. (2012). Data preprocessing for artificial neural network applications in prioritizing railroad projects - a practical experience in Taiwan. Journal of Civil Engineering and Management, 18(4), 483-494. https://doi.org/ 10.3846/13923730.2012.2699914.

Christogiannis, E., \& Pyrgidis, C. (2014). Investigation of the impact of traffic composition on the economic profitability of a new railway 
corridor. Proceedings of the Institution of Mechanical Engineers. Part F: Journal of Rail and Rapid Transit, 228(4), 389-401. https://doi. org/10.1177/0954409713478590.

De Oña, R., Eboli, L., \& Mazzulla, G. (2014). Key factors affecting rail service quality in the northern Italy: a decision tree approach. Transport, 29(1), 75-83. https://doi.org/10.3846/ 16484142.2014.894938.

De Oña, J., De Oña, R., Eboli, L., \& Mazzulla, G. (2015). Heterogeneity in perceptions of service quality among groups of railway passengers, in the northern Italy: a decision tree approach. International Journal of Sustainable Transportation, 9, 612-626. https://doi.org/10.1080/15568318.2013.849318.

De Oña, J., De Oña, R., Eboli, L., Forciniti, C., \& Mazzulla, G. (2016). Transit passengers' behavioural intentions: the influence of service quality and customer satisfaction. Transportmetrica A: Transport Science, 12(5), 385-412. https://dx.doi.org/10.1080/23249935. 2016.1146365.

Dlamini, N. G. (2011). The environmental impacts of various rail passenger ticketing opinions in Japan. Transportation Research Part D: Transport and Environment, 16(5), 365-371. https://doi.org/10.1016/j.trd.2011.02.002.

Eboli, L., \& Mazzulla, G. (2015). Relationships between rail passengers' satisfaction and service quality: a framework for identifying the key service factors. Public Transport, 7(2), 185-201. https://doi. org/10.1007/s12469-014-0096-x.

Eboli, L., Fu, Y., \& Mazzulla, G. (2016). Multilevel comprehensive evaluation of the railway service quality. Procedia Engineering, 137, 21-30. https://doi.org/10.1016/j.proeng.2016.01.230.

Gelumbickas, G., \& Vaičiūnas, G. (2011). Analysis of passenger rolling stock faults and its statistics in Lithuania. Transport, 26(3), 315-319. https://doi.org/10.3846/16484142.2011.618190.

Gudienè, N., Banaitis, A., Podvezko, V., \& Banaitienè, N. (2014). Identification and evaluation of the critical success factors for construction projects in Lithuania: AHP approach. Journal of Civil Engineering and Management, 20(3), 350-359. https://doi.org/ 10.3846/13923730.2014.914082.

Guo, S., Yu, L., Chen, X., \& Zhang, Y. (2011). Modelling waiting time for passengers transferring from rail to buses. Transportation Planning and Technology, 34(8), 795-809. https://doi.org/10.1080/03081060.2011.613589.
Guo, Z., \& Wilson, N. H. M. (2011). Assessing the cost of transfer inconvenience in public transport systems: A case study of the London Underground. Transportation research Part A: Policy and Practice, 45(2), 91-104. https://doi.org/10.1016/j.tra.2010.11.002.

Hadiuzzman, M., Farazi, N. P., Hossain, S., \& Malik, D. M. G. (2017). An exploratory analysis of observed and latent variables affecting intercity train service quality in developing countries. Transportation. https://doi.org./10.1007/s11116-017-9843-6.

Hansen, I. A. (2010). Railway network timetabling and dynamic traffic management. International Journal of Civil Engineering, 8(1), 19-32.

Hashemkhani Zolfani, S., \& Antucheviciene, J. (2012). Team member selecting based on AHP and TOPSIS Grey. Inzinerine Ekonomika - Engineering Economics, 23(4), 425-434. https://doi.org/10.5755/j01ee.23.4.2725.

Hashemkhani Zolfani, S., \& Saparauskas, J. (2013). New application of SWARA method in prioritizing sustainability assessment indicators of energy system. Inzinerine Ekonomika Engineering Economics, 24(5), 408-414. https://doi.org/10.5755/j01.ee.24.5.4526.

Hashemkhani Zolfani, S., Rezaeiniya, N., Pourhossein, M., \& Zavadskas, K. E. (2012). Decision making on advertisement strategy selection based on life cycle of products by applying FAHP and TOPSIS GREY: growth stage perspective; a case about food industry in Iran. Inzinerine Ekonomika - Engineering Economics, 23(5), 471-484. https://dx.doi. org/10.5755/j01.ee.23.5.3134.

Hu, S.-R., \& Liu, C.-T. (2014). Optimizing headways for mass rapid transit services. Journal of Transportation Engineering, 140(11). https://doi.org/10.1061/(ASCE)TE.1943-5436. 0000703.

Jafarian, E., \& Rezvani, M. A. (2012). Application of fuzzy fault tree analysis for evaluation of railway safety risks: an evaluation of root causes for passenger train derailment. Proceedings of the Institution of Mechanical Engineers, Part F: Journal of Rail and Rapid Transit, 226(1), 14-25. https://doi. org/10.1177/095440971403678.

Jánošikova, L., Kavicka, A., \& Bazant, M. (2014). Optimal operation scheduling and platform track assignment in a passenger railway station. Proceedings of the Institution of Mechanical Engineers, Part F: Journal 
of Rail and Rapid Transit, 228(3), 271-284. https://doi.org/10.1177/0954409712472275.

Kandt, J., Rode, P., Hoffman, C., Graff, A., \& Smith, D. (2015). Gauging interventions for sustainable travel: A comparative study of travel attitudes in Berlin and London. Transportation Research Part A: Policy and Practice, 80, 3548. https://doi.org/10.1016/j.tra.2015.07.008.

Kaya, I., \& Kahraman, C. (2014). A comparison of fuzzy multicriteria decision making methods for intelligent building assessment. Journal of Civil Engineering and Management, 20(1), 59-69. https://doi.org/10. 3846/13923730.2013.801906.

Kendall, M., \& Gibbons, J. D. (1990). Rank Correlation Methods (5th ed.). London: Oxford University Press.

Kirschstein, T., \& Meisel, F. (2015). GHGemission models for assessing the eco-friendliness of road and rail freight transports. Transportation Research Part B: Methodological, 73, 13-33. https://doi.org/10.1016/j.trb.2014.12.004.

Lee, A. H. I., Kang, H.-Y., \& Lin, C.-Y. (2014). A performance evaluation model using FAHPI DEA and the Malmquist Productivity Index to assess the photovoltaics industry in Taiwan. Journal of Testing and Evaluation, 42(1), 211-228. https://doi.org/10.1520/JTE20130008.

Maskeliūnaitè, L., \& Sivilevičius, H. (2012). Expert evaluation of criteria describing the quality of travelling by international passenger train: technological, economic and safety perspectives. Technological and Economic Development of Economy, 18(3), 544-566. https://doi.org/10.3846/20294913.2012.710178.

Maskeliūnaitè, L., \& Sivilevičius, H. (2014). The model for evaluating the criteria describing the quality of the trip by international train. Technological and Economic Development of Economy, 20(3), 484-506. https://dx.doi.org/10. 3846/20294913.2014.949333.

Miranda, S., Tavares, P., \& Queiró, R. (2018). Perceived service quality and customer satisfaction: A fuzzy set QCA approach in the railway sector. Journal of Business Research, 89, 371-377. https://doi.org/10.1016/j. jbusres.2017.12.040.

Miroshnichenko, O. F., \& Oginskaya, A. E. (2013). Novye metodicheskie podkhody pri opredelenii ekonomicheskoy effektivnosti passazhirskogo poezda dal'nego sledovaniya $\checkmark$ usloviyakh funktsionirovaniya OAO „,Federal'noy passazhirskoy kompanii“. Vestnik VNIIZHT, 5, 3-7.
Noorzaei, J., Pour, P. M., Jaafar, M. S., Fong, Y. C., \& Thanoon, W. A.-M. (2012). Numerical simulation of railway track supporting system using finite-infinite and thin layer elements under impulsive loads. Journal of Civil Engineering and Management, 18(2), 245-252. https://doi.org/10.3846/13923730.20 12.671286 .

Nowell, R., \& Sutton, A. (2011). The benefits and development of windows with improved passenger containment. Proceedings of the Institution of Mechanical Engineers, Part F: Journal of Rail and Rapid Transit, 225(3), 247-257. https://doi. org/10.1243/09544097JRRT388.

Paha, J., Rompf, D., \& Warneeke, C. (2013). Customer choice patterns in passenger rail competition. Transportation Research Part A: Policy and Practice, 50, 209-227. https://doi. org/10.1016/j.tra.2013.01.037.

Persson, R. (2010). Tilting trains: benefitsand motion sickness. Proceedings of the Institution of Mechanical Engineers, Part F: Journal of Rail and Rapid Transit, 224(6), 513-522. https://doi. org/10.1243/09544097JRRT282.

Podvezko, V., \& Sivilevičius, H. (2013). The use of AHP and rank correlation methods for determining the significance of the interaction between the elements of a transport system having a strong influence on traffic safety. Transport, 28(4), 389-403. https://doi.org/10.38 46/16484142.2013.866980.

Saaty, T. L. (1980). The Analytic Hierarchy Process. New York: McGraw-Hill.

Seelhorst, M., \& Liu, Y. (2015). Latent air travel preferences: understanding the role of frequent flyer programs on itinerary choice. Transportation Research Part A: Policy and Practice, 80, 49-61. https://dx.doi.org/10.1016/ j.tra.2015.07.007.

Sivilevičius, H. (2011). Application of expert evaluation method to determine the importance of operating asphalt mixing plant quality criteria and rank correlation. The Baltic Journal of Road and Bridge Engineering, 6(1), 48-58. https://doi. org/10.3846/bjrbe.2011.07.

Sivilevičius, H., \& Maskeliūnaitè, L. (2014). The numerical example for evaluating the criteria describing the quality of the trip by international train. E\&M Ekonomie a Management, 17(2), 73-86. https://dx.doi. org.10.15240/tul/001/2014-2-006/1648.

Sivilevičius, H., Maskeliūnaitè, L., Petkevičienè, B., \& Petkevičius, K. (2012). The 
model of evaluating the criteria, describing the quality of organization and technology of travel by international train. Transport, 27(3), 307-319. https://dx.doi.org/10.38464142.2012.724448.

Sivilevičius, H., \& Maskeliūnaitè, L. (2018). Multiple criteria evaluation and the inverse hierarchy model for justifying the choise of rail transport mode. Promet - Traffic \& Transportation, 30(1), 57-69. https://doi. org/10.7307/ptt.v30i1.2417.

Šoltés, V., \& Gavurová, B. (2014). The functionality comparison of the health care by the Analytical Hierarchy process method. E\&M Ekononie a Management, 17(3), 100-117. https://doi.org/10.15240/tul/001/2014-3-009.

Vaičiūnas, G., \& Bureika, G. (2014). Approach modelling of constant interfailure process of renewal multi-unit fleet. Eksploatacja i Niezavodność-Maintenance and Reliability, 16(3), 415-421.

Vidal, L.-A., Marle, F., \& Bacquet, J.-C. (2011). Using a Delphi process and the Analytic Hierarchy Process (AHP) to evaluate the complexity of projects. Expert Systems with Applications, 38(5), 5388-5405. https://doi. org/10.1016/j.eswa.2010.10.016.

Vitić-Ćetković, A., \& Bauk, S. (2014). E-services and positioning of passenger ports in the context of cruise tourism promotion. Promet - Traffic\&Transportation, 26(1), 83-93.

Wang, W.-C., Yu, W.-d., Yang, I-T., Lin, C.-C., Lee, M.-T., \& Cheng, Y.-Y. (2013). Applying the AHP to support the best-value contractor selection-lessons learned from two case studies in Taiwan. Journal of Civil Engineering and Management, 19(1), 24-36. https://doi.org/10.3846/13923730.2012.734851.

Woo, C. K., Cheng, Y. S., Li, R., Chiu, A., Ho, S. T., \& Horowitz, I. (2015). Can Hong Kong price-manage its cross-harbor-tunnel congestion? Transportation Research Part A:
Policy and Practice, 82, 94-109. https://doi. org/10.1016/j.tra.2015.09.002.

Yaghini, M., Nikoo, N., \& Ahadi, H. R. (2014). An integer programming model for analysing impacts of different train types on railway line capacity. Transport, 29(1), 28-35. https://doi. org/10.3846/16484142.2014.894938.

Zalar, D., Užpalytè-Vitkūnienè, R., Rebolj, D., \& Lep, M. (2018). Amethodological framework for measuring the level of convenience of transport ticketing systems. Transport, 33(4), 1005-1016. https://doi.org/10.3846/16484142. 2017.1300783.

Zavadskas, E. K., \& Podvezko, V. (2016). Integrated determination of objective criteria weights in MCDM. International Journal of Information Technology \& Decision Making, 15(2), 267-283. https://doi.org/10.1142/ S0219622016500036.

Zhao, J., \& Deng, W. (2013). Fuzzy multiobjective decision support model for urban rail transit projects in China. Transport, 28(3), 224-235. https://doi.org/10.3846/16484142. 2013.829119.

prof. Henrikas Sivilevičius, habil. dr. Vilnius Gediminas Technical University Faculty of Transport Engineering Department of Mobile Machinery and Railway Transport Lithuania henrikas.sivilevicius@vgtu.It

doc. Lijana Maskeliūnaitè dr. Vilnius Gediminas Technical University Faculty of Transport Engineering Department of Mobile Machinery and Railway Transport Lithuania lijana.maskeliunaite@vgtu.It 


\title{
Abstract
}

\section{THE MODEL ASSESSING THE IMPACT OF PRICE AND PROVIDED SERVICES ON THE QUALITY OF THE TRIP BY TRAIN: MCDM APPROACH}

\author{
Henrikas Sivilevičius, Lijana Maskeliūnaitė
}

Long-distance transportation of passengers is usually performed by air and rail transport. The time and cost of the trip, as well as quality and variety of services and other economic criteria, strongly influence the choice of one of the competing transport facilities. The quality of the trip by train is determined by the criteria of four groups associated with the vehicle elements and the state of the railway line, organization of the trip by train, its technology, the price of the trip and the provided services (PTPS) and safety of the trip by train. The paper presents a model of the major component of the comprehensive quality index (CQI), characterizing a trip by an international train from such aspects as the PTPS. Based on using the analytic hierarchy process (AHP), the weights of these criteria groups and the weights of the criteria of each group are determined. A survey of the respondents of three categories, including passengers, service staff of the train and the administration staff of the joint-stock company, is conducted to know their opinions about various aspects of the trip described by the considered criteria. The model is based on the average weight and the weights of six criteria of the group, describing the PTPS, which are multiplied by the calculated variables. This allows the quality of the trip by train, depending only on these criteria, to be expressed in a single number. The numerical example shows that the suggested model yields reliable data and can be used in practice for evaluating the quality of trips by various international trains.

Key Words: Transportation, railway trip quality, international train, passenger services, MCDM methods, practical application.

JEL Classification: CO2, R4, L62, L92.

DOI: 10.15240/tul/001/2019-2-004 